\title{
Spatial differences in prey preference by tigers across the Bangladesh Sundarbans reveal a need for customised strategies to protect prey populations
}

\author{
M. Abdul Aziz ${ }^{1,3, *}$, M. Anwarul Islam², Jim Groombridge ${ }^{1}$ \\ ${ }^{1}$ Durrell Institute of Conservation and Ecology, School of Anthropology and Conservation, University of Kent, \\ Canterbury CT2 7NZ, UK \\ ${ }^{2}$ Department of Zoology, University of Dhaka, Dhaka 1000, Bangladesh \\ ${ }^{3}$ Present address: Department of Zoology, Jahangirnagar University, Savar, Dhaka 1342, Bangladesh
}

\begin{abstract}
The Sundarbans is the only mangrove habitat in the world to support tigers Panthera tigris, whose persistence there is believed to be dependent on a very limited number of prey species. Conservation managers therefore need to understand how tigers utilise available prey species on a spatial scale in order to formulate a prey-based protection strategy for this global-priority tiger landscape. A total of 512 scat samples were collected during a survey of $1984 \mathrm{~km}^{2}$ of forest across 4 sample blocks in the $6017 \mathrm{~km}^{2}$ of the Bangladesh Sundarbans. Analysis of scat composition and prey remains reliably identified 5 major prey species, of which spotted deer Axis axis and wild pig Sus scrofa contributed a cumulative biomass of $89 \%$ to tiger diet. Tiger preference for prey species was highly skewed towards spotted deer and wild pig, but the relative contribution of these 2 species differed significantly across the 4 study areas, which spanned the Sundarbans, demonstrating important spatial patterns of tiger prey preference across the Sundarbans landscape. Given the comparatively limited number of prey species available to support the dwindling tiger population, different strategies are needed in different parts of the Sundarbans to support tiger populations and to protect spotted deer and wild pig populations from unabated poaching.
\end{abstract}

KEY WORDS: Bangladesh $\cdot$ Mangrove $\cdot$ Panthera tigris $\cdot$ Tiger prey preference $\cdot$ Scat $\cdot$ Sundarbans $\cdot$ Spotted deer

\section{INTRODUCTION}

Wild felids are keystone predators in their habitats (Mills et al. 1993, Power et al. 1996), where they play a key role in shaping the prey communities (Karanth \& Sunquist 2000). On an ecosystem level, tigers Panthera tigris are apex predators (Seidenstricker et al. 1999) that regulate ecological processes across the landscapes they inhabit (Sunquist et al. 1999). At the same time, prey communities are the crucial determinants of where in those landscapes tigers can survive (Karanth \& Sunquist 2000). The Sundarbans cover an area of $10262 \mathrm{~km}^{2}$ shared between Bangladesh and India (Giri et al. 2007) and are known to

\footnotetext{
${ }^{*}$ Corresponding author: maaziz78@gmail.com
}

support one of the 5 most important tiger populations in the world (Wikramanayake et al. 1998, Aziz et al. $2017 b)$. This vast region contains a relatively limited number of prey species compared to other tiger habitats (Khan 2008, Aziz 2017) and is the only mangrove habitat where tigers survive (Sanderson et al. 2006).

Tigers inhabiting the mangrove forests of the Sundarbans prey upon a limited number of species of medium-sized ungulates compared to the wider range of medium- to large-sized ungulates that commonly occur in most other tiger landscapes (Karanth et al. 1995, Wang \& Macdonald 2009, Miquelle et al. 2010, Hayward et al. 2012). Several large ungulate species, including wild water buffalo Bubalus arnee,

() The authors 2020. Open Access under Creative Commons by Attribution Licence. Use, distribution and reproduction are unrestricted. Authors and original publication must be credited. 
swamp deer Rucervus duvaucelii and hog deer Axis porcinus, were extirpated from the Sundarbans at the beginning of the last century (Curtis 1933, Seidenstricker \& Hai 1983, Blower 1985), whilst those that survive today comprise only the spotted deer Axis axis, wild pig Sus scrofa and barking deer Muntiacus muntjac. The abundance and distribution of these remaining ungulates are likely to be influenced by local differences in the heterogeneous habitat types across the Sundarbans landscape, and therefore predation of these species by tigers may also vary spatially.

Although distribution and density of tigers is largely determined by the density of their primary prey species (Karanth et al. 2004, Miquelle et al. 2010), prey selection depends on the relative density of species in their habitat (Johnsingh 1983, Karanth et al. 1995, Wang \& Macdonald 2009). Prey selection by tigers can provide critical information about their life history strategy and response to prey distribution and densities (Miquelle et al. 1996, Sunquist et al. 1999). Furthermore, understanding the primary components of tiger diet is a fundamental requirement in designing effective and long-term conservation strategies for tigers and their prey animals (Kerley et al. 2015). However, there is a substantial lack of information on tiger diet in the Bangladesh Sundarbans in relation to their abundance and spatial distribution (Ahmad et al. 2009). Previous studies in the Sundarbans focussing on tiger diet covered less than $5 \%$ of the landscape area and were therefore prone to sampling artefacts (Reza et al. 2001, Khan 2008). Given that the abundance and distribution of key prey species across the Sundarbans may have radically changed in response to human impacts over the past decade, the lack of up-to-date information about tiger prey leaves tiger conservation strategies at risk of being ineffective. Therefore, this study aimed to (1) provide an updated dietary profile of tigers from across the Sundarbans, and (2) investigate if there are any differences in choice of major prey species by tigers across the different regions and habitat types found there.

\section{MATERIALS AND METHODS}

\subsection{Study sites}

The Bangladesh Sundarbans covers $6017 \mathrm{~km}^{2}$, and comprises $51 \%$ of the national forest coverage (Wahid et al. 2007). The forest land area covers $4143 \mathrm{~km}^{2}$, and the remainder comprises a maze of numerous estuaries, rivers, channels and creeks. The Sundarbans is bordered to the south by the Bay of Bengal and to the north and east by a landmass dominated by human settlements (Hussain \& Acharya 1994). Two rivers, the Raimangal and the Haribhanga, mark the international boundary between Bangladesh and India, and separate the Indian part of the Sundarbans. Within the Bangladesh Sundarbans, 3 separate areas were declared as wildlife sanctuaries: the Sundarbans East $\left(383 \mathrm{~km}^{2}\right)$, Sundarbans South $\left(370 \mathrm{~km}^{2}\right)$ and Sundarbans West $\left(715 \mathrm{~km}^{2}\right)$ sanctuaries. These sanctuaries were collectively declared a UNESCO World Heritage Site in 1997 (Iftekhar \& Islam 2004b).

The Sundarbans mangrove consists of tropical moist forests, with a maritime, humid, and tropical climate marked by seasonality in weather patterns (Hussain \& Acharya 1994). The forest is rich in biological diversity, supporting at least 330 species of plants, 400 fishes, 35 reptiles, 300 birds and 42 mammals (Hussain \& Acharya 1994). Within this diverse forest system, the tiger is the only large terrestrial carnivore, and is known to include spotted deer and wild pig as its major prey species (Reza et al. 2001, Khan 2008). Three small carnivores found in the Sundarbans forests are the fishing cat Prionailurus viverrinus, jungle cat Felis chaus and leopard cat $P$. bengalensis. Large Indian civet Viverra zibetha and Asiatic golden jackal Canis aureus are also present in the study area.

The 2 dominant tree species in the mangrove forest are the sundri Heritiera fomes (39\%) and gewa Excoecaria agallocha (39\%); other species constitute only $16 \%$ of forest cover (Iftekhar \& Saenger 2008). Most of the forest is less than $1 \mathrm{~m}$ above sea level (Canonizado \& Hossain 1998) and consists of vegetated islands with a tidal mean amplitude of 3-4 m (Chaffey et al. 1985, Gopal \& Chauhan 2006).

\subsection{Scat sampling}

Four sampling areas providing representative coverage $(33 \%)$ of the Bangladesh Sundarbans and covering a total of $1984 \mathrm{~km}^{2}$ were intensively searched for putative scat of tigers. The sample areas were the Satkhira Block (SB), West Wildlife Sanctuary (WS), East Wildlife Sanctuary (ES) and Chandpai Block (CB) (Fig. 1, Table 1). Location, protection status and level of human use were considered in selecting these sampling sites (Aziz et al. 2017a).

Each sample block was divided into $4 \mathrm{~km}^{2}$ grid squares that provided a total of 373 grid cells for intensive sampling. Five survey teams, including 1 trained field staff member in each team, walked along a transect in each grid square. Starting points for each transect were selected where the grid square 


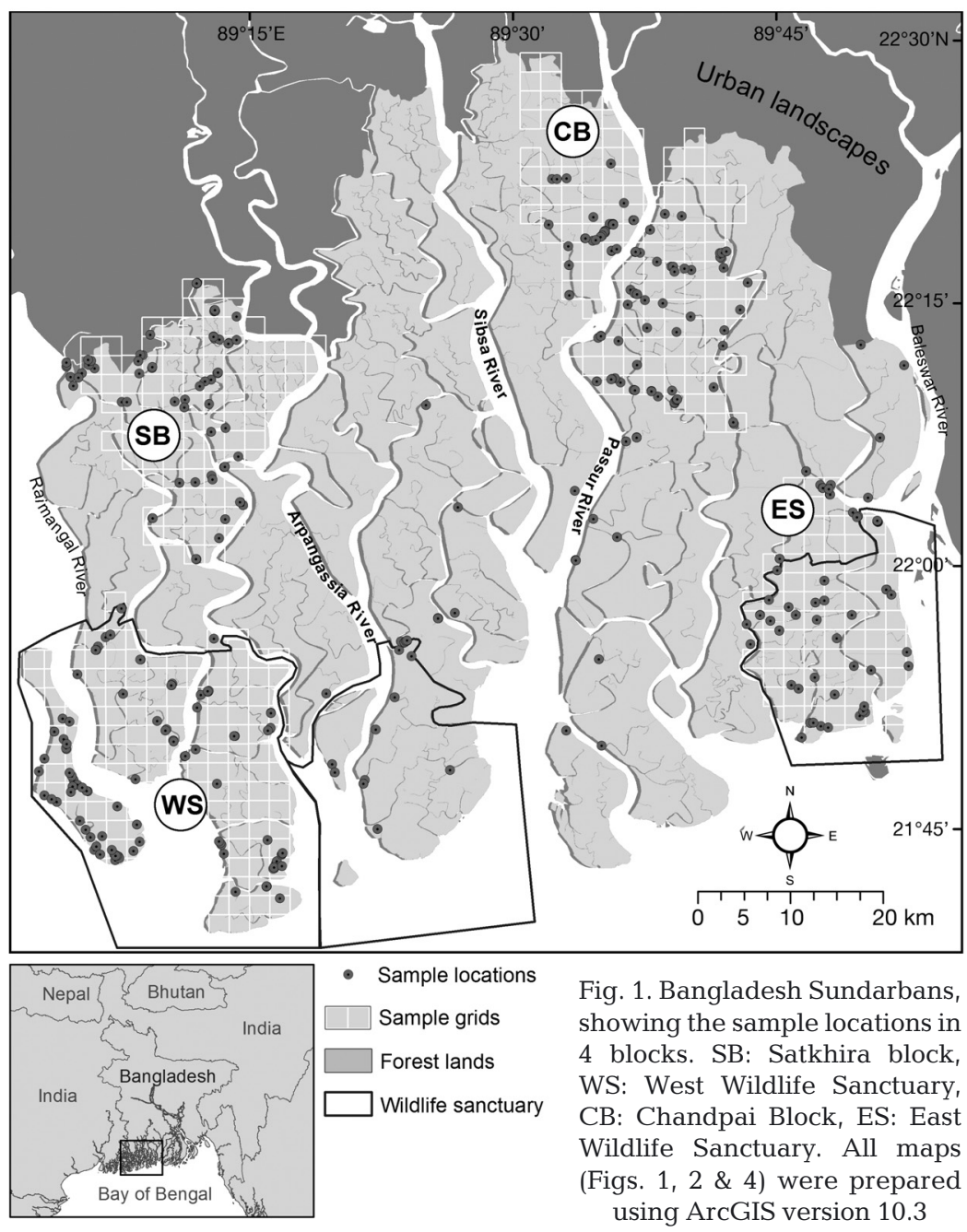

winter months (Table 1). Tiger scat was identified by examining physical characteristics of scats and associated secondary signs of tigers (Karanth et al. 1995). Geographic coordinates of each scat sample and transect tracks were recorded using a handheld Garmin GPSMAP 64 GPS. In addition, count data on the following prey species were collected using a distance sampling technique with minor adjustments (Buckland et al. 2001): spotted deer, wild pig, rhesus macaque Macaca mulatta, barking deer and water monitor Varanus salvator. When prey species were encountered, each team recorded species name, number of individuals and group size.

\subsection{Scat analysis}

Only a representative portion of each scat was collected in polystyrene containers, then air dried and transported to the Conservation Genetics Laboratory at the Durrell Institute for Conservation and Ecology (DICE) of the University of Kent, UK, for analyses. After identification as tiger scat through DNA screening (scats were primarily collected for a non-invasive study of genetic diversity; see Aziz et

could be easily accessed by boat anchored on the river bank. Each grid square was repeatedly (1 to 3 transects) searched for a total of $855 \mathrm{~km}$ of transects in all sample blocks. Alongside this sample collection, opportunistic samples were collected from outside of intensively sampled blocks (Fig. 1).

A total of 512 scat samples were collected between 20 November 2014 and 23 March 2015, limited to only al. 2017b, 2018), each scat was soaked in water and washed through a strainer to isolate undigested remains of hairs, bones, hooves, scales and feathers for analyses. The hair of prey species was the primary source of information to detect the prey consumed by tigers (Sunquist 1981, Karanth et al. 1995). Several hairs were collected from each scat sample and were compared with reference hairs of prey species col-

Table 1. Sample area, number of scat samples used and number of prey species detected along transects. For birds, fishes and crabs, respectively, all species were considered as 1 entity

\begin{tabular}{|lcccccc|}
\hline Sample area & Protection status & $\begin{array}{c}\text { Area } \\
\left(\mathrm{km}^{2}\right)\end{array}$ & $\begin{array}{c}\text { Transect } \\
\text { length }(\mathrm{km})\end{array}$ & $\begin{array}{c}\text { Samples } \\
\text { collected }\end{array}$ & $\begin{array}{c}\text { Samples } \\
\text { analysed }\end{array}$ & $\begin{array}{c}\text { No. of prey } \\
\text { species detected }\end{array}$ \\
\hline Satkhira Block & Reserve forest & 342 & 198 & 77 & 67 & 6 \\
West Wildlife Sanctuary & Protected area & 715 & 166 & 152 & 115 & 6 \\
East Wildlife Sanctuary & Protected area & 383 & 167 & 84 & 81 & 7 \\
Chandpai Block & Reserve forest & 544 & 202 & 127 & 111 & 8 \\
Opportunistic sampling region & Both types & - & 122 & 72 & 66 & 7 \\
\hline
\end{tabular}


lected from kills and captive animals. General characteristics of hairs, including colour, length, thickness and pattern of cortex pigmentation, were used to identify prey species (Karanth et al. 1995, Andheria et al. 2007). Remains of claws and hooves in scat samples were also used to identify prey species alongside hairs. Presence of a species in any one scat sample was recorded as a single occurrence (Kerley et al. 2015).

\subsection{Data analyses}

Relative abundances of spotted deer and wild pig were assessed using data obtained from distance sightings across the 4 sampling sites. Given the limited sample size of major prey animals (Buckland et al. 2001), only relative abundance (number of individuals per $\mathrm{km}$ of transect walked), mean group size and abundance variations across sample sites were estimated using standard statistical procedures. The topography of the survey area is covered with numerous pneumatophores (mangroves) and creeks with dense vegetation, which limited visibility for the application of distance sampling.

For scat analysis, the frequency of occurrence (FO) was calculated as a percentage of a particular species in the total number of prey items found in the samples. FO is a commonly used measure of prey intake and composition, but this measure can be misleading if the body sizes of different prey items are highly variable (Floyd et al. 1978, Ackerman et al. 1984). An alternative regression model was therefore used following Ackerman et al. (1984) in order to estimate corrected prey frequency to diets, by applying the equation:

$$
Y=1.980+0.035 X
$$

where $X$ is the average live weight of a prey animal consumed, and $Y$ is the weight of the consumed prey represented by 1 field-collectible scat.

This regression model has been adopted in diet investigations of tigers and other carnivores (Karanth et al. 1995) and subsequently applied to a number of similar studies across tiger-occupied landscapes in India (Biswas \& Sankar 2002, Andheria et al. 2007). Using the correction factor $Y$ from the above regression model, the relative biomass (RB), and the relative number of a prey species consumed (RN) were estimated with the equations:

$$
\begin{gathered}
\mathrm{RB}=(\mathrm{FO} \times Y) / \Sigma(\mathrm{FO} \times Y) \times 100 \\
\mathrm{RN}=(D / X) \Sigma(\mathrm{RB} \times X) \times 100
\end{gathered}
$$

To investigate spatial patterns of prey occurrence, prey data were grouped into 4 geographic sample regions: $\mathrm{SB}, \mathrm{WS}, \mathrm{CB}$ and $\mathrm{ES}$. We performed an initial analysis using global Moran's I-test in the ArcGIS 10.3 platform, separately for each sampling block to check for potential autocorrelation, and the same was done by grouping samples into 3 temporal datasets obtained from 3 repeated transect sessions. Moran's $I$ indexes for both spatial (ranges from -0.15 to -0.11 ) and temporal (ranges from -0.15 to -0.48 ) scales were negligible, so we carried out a $\chi^{2}$ test in Microsoft Excel 2010 to assess whether the frequency of prey species in tiger scat varied substantially across sampled regions.

The preference of prey selected by tigers was estimated using Jacobs' index (Jacobs 1974), which ranges in values from +1 (strongly preferred) to -1 (strongly avoided). Analyses of preference were determined using the R package 'selectapref' (Richardson 2020) for spotted deer, wild pig, barking deer, rhesus macaque and water monitor considering their relatively larger biomass and contribution to tiger diet. Scores derived from Jacobs' index represent proportionate consumption of prey species relative to their relative abundance across sample sites.

All maps were prepared using ArcGIS version 10.3 .

\section{RESULTS}

We surveyed $733 \mathrm{~km}$ of transects within 346 grid squares in the 4 sample blocks, and an additional $122 \mathrm{~km}$ of opportunistic transects outside of these blocks. From this sampling effort, we collected 512 tiger scats. Of these, 72 scats remained unidentified, containing entirely soil and self-groomed hair, remains of crabs $(n=21)$, remains of fishes $(n=18)$ and remains of birds ( $n=9$ ) (Fig. 2). These scats were excluded from biomass conversion to avoid underestimates of major prey species. Most of these samples contained large volumes of soil and some quantity of grass blades and tree leaves.

\subsection{Spatial pattern of prey consumption}

Five major prey species were identified from scat samples (Table 2), excluding remains of crabs, fishes and birds. Remains of spotted deer and wild pig provided 78 and $11 \%$ of relative prey biomass, respectively, to tiger diet. The remaining $11 \%$ relative prey biomass came from barking deer $(7 \%)$, rhesus 

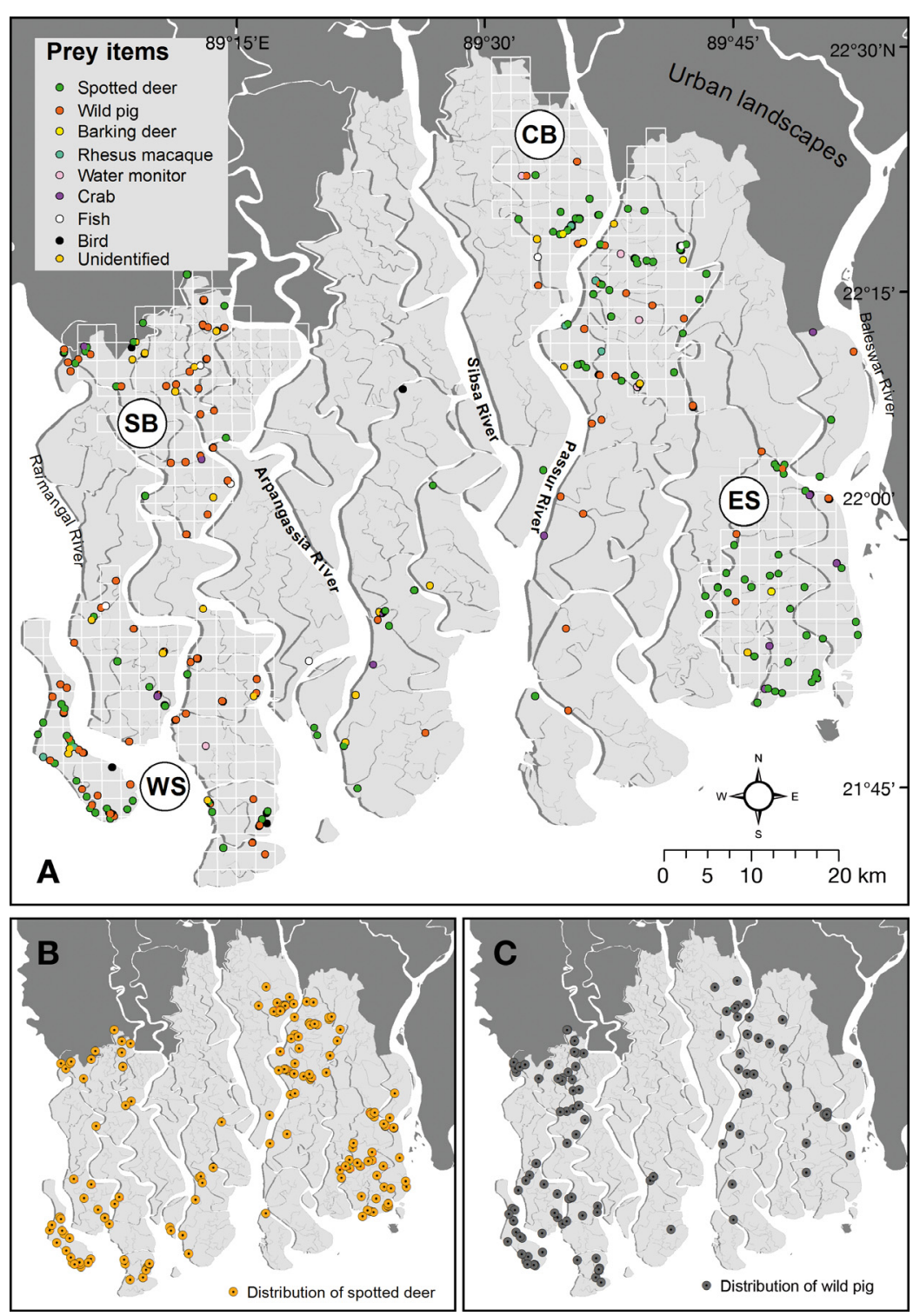

Fig. 2. (A) Spatial location of all food items; (B) distribution of spotted deer; and (C) distribution of wild pig preyed upon by tigers in the Sundarbans of Bangladesh. Abbreviations as in Fig. 1 macaque $(2 \%)$ and water monitor ( $2 \%$ ). Sample block-wise results show that wild pig comprised the highest percentage of prey biomass in tiger diets at SB (63\%) and WS (49\%), while spotted deer comprised the highest percentage of prey biomass at CB $(81 \%)$ and $\operatorname{ES~}(72 \%)$. No prey remains of barking deer were found in scats collected from SB and WS. The frequency of spotted deer and wild pig in tiger diet differed significantly $\left(\chi^{2}<\right.$ 0.0001 , df $=3, \mathrm{p}<0.05$ ) across the 4 sample blocks.

\subsection{Prey availability and preference}

Spotted deer, rhesus macaques and wild pigs were sighted in all sample blocks. On a spatial scale, spotted deer were the predominant prey species at ES and CB, while wild pigs predominated in the SB and WS. Of the remaining 3 prey species, rhesus macaques were found across 4 sites, with higher relative counts in SB and CB. Water monitors were relatively rare across all sites, and barking deer were entirely absent in SB and WS (Fig. 3). The mean \pm SE group size of spotted deer was $4.63 \pm 1.74(\mathrm{n}=38)$ whereas it was $2.88 \pm 0.55(\mathrm{n}=26)$ for wild pig and $12.10 \pm 1.25(\mathrm{n}=37)$ for rhesus macaque. Barking deer $(\mathrm{n}=4)$ and water monitor ( $\mathrm{n}=13$ ) were encountered only as single individuals.

Overall, spotted deer were tigers' preferred prey, with wild pigs as a

Table 2. Relative frequency (FO), relative biomass (RB) of prey species and relative number of that prey species consumed (RN) by tigers in 4 sample blocks of the Sundarbans

\begin{tabular}{|c|c|c|c|c|c|c|c|c|c|c|c|c|c|c|c|}
\hline \multirow[b]{2}{*}{ Prey species } & \multicolumn{3}{|c|}{ Satkhira block } & \multicolumn{3}{|c|}{$\begin{array}{c}\text { West Wildlife } \\
\text { Sanctuary }\end{array}$} & \multicolumn{3}{|c|}{$\begin{array}{c}\text { East Wildlife } \\
\text { Sanctuary }\end{array}$} & \multicolumn{3}{|c|}{ Chandpai block } & \multicolumn{3}{|c|}{ Overall average } \\
\hline & $\mathrm{FO}$ & $\mathrm{RB}$ & $\mathrm{RN}$ & $\mathrm{FO}$ & $\mathrm{RB}$ & $\mathrm{RN}$ & $\mathrm{FO}$ & $\mathrm{RB}$ & $\mathrm{RN}$ & $\mathrm{FO}$ & $\mathrm{RB}$ & $\mathrm{RN}$ & $\mathrm{FO}$ & $\mathrm{RB}$ & RN \\
\hline Spotted deer & 31 & 34.22 & 24.23 & 44 & 48.59 & 36.49 & 68 & 72.29 & 53.65 & 78 & 81.22 & 68.19 & 57 & 77.78 & 58.12 \\
\hline Wild pig & 65 & 63.41 & 65.94 & 53 & 49.29 & 54.36 & 24 & 21.89 & 23.86 & 16 & 14.43 & 17.79 & 38 & 11.44 & 12.56 \\
\hline Rhesus macaque & 2 & 1.19 & 4.68 & 2 & 1.42 & 5.89 & 3 & 1.89 & 7.77 & 2 & 1.33 & 6.15 & 2 & 2.23 & 9.23 \\
\hline Barking deer & 0 & 0 & 0 & 0 & 0 & 0 & 1 & 1.13 & 1.87 & 3 & 2.37 & 4.45 & 1 & 6.58 & 10.99 \\
\hline Water monitor & 2 & 1.02 & 5.16 & 1 & 0.7 & 3.25 & 4 & 2.78 & 12.85 & 1 & 0.65 & 3.39 & 2 & 1.97 & 9.09 \\
\hline
\end{tabular}




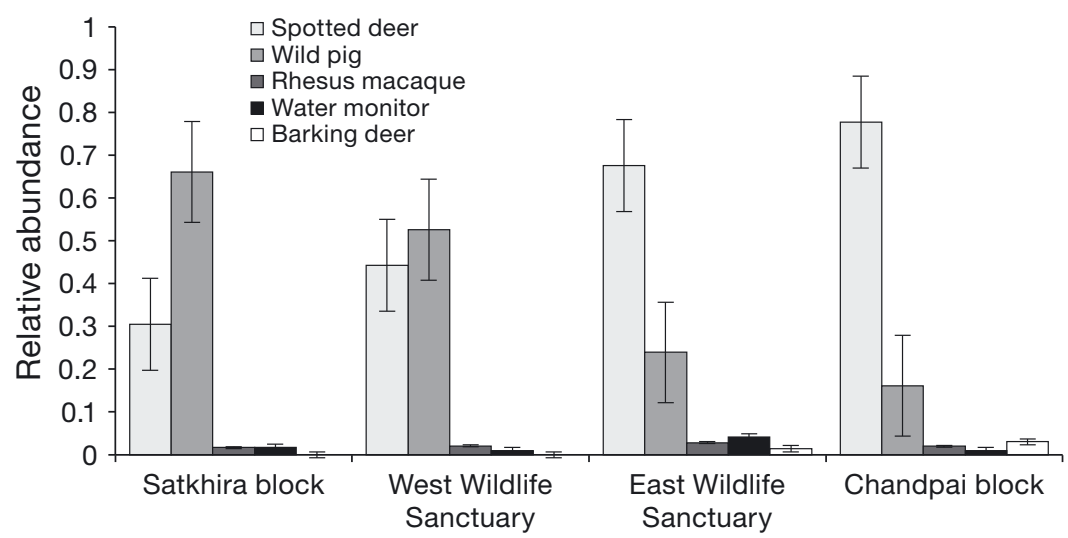

Fig. 3. Relative abundance of tiger prey species estimated by distance sampling counts in 4 sample regions

Table 3. Jacobs' index scores measuring tiger preference for, or avoidance of, 5 major prey species at 4 sample sites in the Sundarbans of Bangladesh. WS: Wildlife Sanctuary

\begin{tabular}{|lrrrrr|}
\hline Species & $\begin{array}{c}\text { Satkhira } \\
\text { Block }\end{array}$ & West WS & East WS & $\begin{array}{c}\text { Chandpai } \\
\text { Block }\end{array}$ & Overall \\
\hline Spotted deer & 0.3518 & 0.3845 & 0.5277 & 0.4737 & 0.4706 \\
Wild pig & 0.7506 & 0.4787 & 0.1685 & 0.1697 & 0.3632 \\
Barking deer & -0.6934 & -0.5372 & -0.0764 & -0.6638 & -0.7413 \\
Rhesus macaque & -1.0000 & -1.0000 & -0.8893 & -0.7582 & -0.8790 \\
Water monitor & -0.9068 & -0.9181 & -0.6936 & -0.6526 & -0.8272 \\
\hline
\end{tabular}

secondary alternative in their diet. However, sample block-wise results show that preference for wild pigs was higher in SB and WS, whereas the preference for spotted deer was highest in ES and CB. The remaining 3 species were least preferred by tigers across all sample blocks (Table 3).

\section{DISCUSSION}

\subsection{Spatial pattern of prey consumption}

Spotted deer and wild pig contributed $89 \%$ prey biomass to tiger diets in the mangrove forest of the Bangladesh Sundarbans (Table 4). Our study reveals for the first time the spatial variation in prey consumption by tigers in the Sundarbans where there is a clear segregation of spotted deer and wild pig distribution on an east-west axis. Specifically, wild pig superseded spotted deer in prey biomass contribution to tiger diets in the western parts of the Sundarbans, as observed in SB and WS, whilst the opposite was true for ES and CB (Fig. 4). We assume that variation in distribution patterns of spotted deer and wild pig could be influenced by vegetation type as well as different extents of poaching pressure on prey populations across the Sundarbans (Mohsanin et al. 2013, Aziz et al. 2017a). In the context of the Sundarbans landscape, the survival of tigers therefore depends on the spotted deer and wild pig populations, in an already modified environment where several large ungulates, including wild buffalo, swamp deer and hog deer, have been extirpated (Curtis 1933, Seidenstricker \& Hai 1983, Blower 1985). The indiscriminate killing by humans is believed to be the main cause of these historic extinction events (Seidenstricker \& Hai 1983). A relatively recent study reported over 11000 spotted deer being poached annually from the Bangladesh Sundarbans for local consumption (Mohsanin et al. 2013). This illegal and covert activity appears to remain unaddressed and could wipe out the most important prey animal, the spotted deer, on which the future of our last tigers rests. Indeed, we note that the Indian Sundarbans has already lost its last barking deer (Sahgal et al. 2007), and this species has also become a rarity on the Bangladesh side of the Sundarbans, with no sighting or scat remains of this species observed in this study in the south-western parts of the forest. Although the contribution of this ungulate to tiger diet may be small, its disappearance may be a symptom of a wider crisis of tiger habitats in the Sundarbans. The habitat suitability of this browsing ungulate might have been significantly undermined by vegetation changes resulting from increasing salinity (Iftekhar \& Islam 2004a, Wahid et al. 2007) as well as by adverse human activities (Aziz et al. 2013, 2017a). Any further loss of any of the remaining ungulate species and/or individuals from the Sundarbans will therefore undoubtedly jeopardise the future of the last tigers in this region.

Our results contrast with those of Khan (2008), who found that spotted deer alone made up $80 \%$ of relative frequency, along with $11 \%$ by wild pig, whilst Reza et al. (2001) recorded the contribution of spotted deer and wild pig to tiger diet as being 69 and $15 \%$, respectively (Reza et al. 2001). Together, these findings suggest that the higher frequency of spotted deer found in previous studies might be a conse- 
Table 4. Comparison of relative biomass of prey species of tigers in different habitat types. Note the high percentages of biomass of major prey species, especially spotted deer and wild pig, in tiger diet. n: number of scat samples

\begin{tabular}{|c|c|c|c|}
\hline $\begin{array}{l}\text { Tiger habitats, } \\
\text { no. of samples } \\
\text { and reference }\end{array}$ & Tiger prey species & Prey scientific name & $\begin{array}{c}\text { Relative } \\
\text { biomass } \\
\text { (\%) }\end{array}$ \\
\hline \multirow{5}{*}{$\begin{array}{l}\text { Sundarbans } \\
\text { Mangrove Forest, } \\
\text { Bangladesh; } \\
\mathrm{n}=512 \\
\text { (this study) }\end{array}$} & Spotted deer & Axis axis & 77.78 \\
\hline & Wild pig & Sus scrofa & 11.44 \\
\hline & Rhesus macaque & Macaca mulatta & 2.23 \\
\hline & Barking deer & Muntiacus muntjak & 6.58 \\
\hline & Water monitor & Varanus salvator & 1.97 \\
\hline \multirow{8}{*}{$\begin{array}{l}\text { Bandipur Tiger } \\
\text { Reserve, India; } \\
\mathrm{n}=381 \\
\text { (Andheria } \\
\text { et al. 2007) }\end{array}$} & Gaur & Bos gaurus & 42.31 \\
\hline & Sambar & Cervus unicolor & 30.89 \\
\hline & Spotted deer & Axis axis & 18.79 \\
\hline & Wild pig & Sus scrofa & 4.39 \\
\hline & Barking deer & Muntiacus muntjak & 0.98 \\
\hline & Four-horned antelope & Tetracerus quadricornis & 0.44 \\
\hline & Langur & Semnopithecus entellus & 0.75 \\
\hline & Chevrotain & Tragulus meminna & 0.43 \\
\hline \multirow{6}{*}{$\begin{array}{l}\text { Bhutan's Jigme } \\
\text { Singye Wangchuck } \\
\text { National Park; } \\
\text { n = } 29 \text { (Wang \& } \\
\text { Macdonald 2009) }\end{array}$} & Sambar & Cervus unicolor & 26.80 \\
\hline & Barking deer & Muntiacus muntjak & 6.80 \\
\hline & Wild pig & Sus scrofa & 3.30 \\
\hline & Cattle & - & 44.00 \\
\hline & Yak & - & 22.90 \\
\hline & Sheep & - & 2.80 \\
\hline \multirow{11}{*}{$\begin{array}{l}\text { Lazovskii State } \\
\text { Nature Zapovednik, } \\
\text { Russian Far East; } \\
\text { n=770 } \\
\text { (Kerley et al. 2015) }\end{array}$} & Sika deer & Cervus nippon & 15.49 \\
\hline & Roe deer & Capreolus pygargus & 1.75 \\
\hline & Red deer & Cervus elaphus & 4.72 \\
\hline & Wild pig & Sus scrofa & 32.66 \\
\hline & Long-tailed goral & Naemorhedus caudatus & 0.55 \\
\hline & Amur tiger & Panthera tigris altaica & 0.19 \\
\hline & Bear spp. & Ursus spp. & 7.12 \\
\hline & Racoon dog & Nyctereutes procyonoides & es 0.55 \\
\hline & Asian badger & Meles leucurus & 1.94 \\
\hline & Dog & - & 0.60 \\
\hline & Cow & - & 0.69 \\
\hline
\end{tabular}

quence of the smaller sampling coverage of just $20 \mathrm{~km}^{2}$ (Reza et al. 2001) and $312 \mathrm{~km}^{2}$ (Khan 2008) out of $6017 \mathrm{~km}^{2}$ of the Bangladesh Sundarbans. Several studies elsewhere have argued that a relatively larger geographic area $\left(>500 \mathrm{~km}^{2}\right)$ is likely to provide robust sample sizes to precisely capture dietary patterns of carnivores (Andheria et al. 2007), including prey selectivity of tigers (Kapfer et al. 2011). Furthermore, the ES, located in the south-eastern part of the Sundarbans of Bangladesh, is more accessible to researchers, and reportedly enriched with preferable ungulate habitats (sungrass, open meadows and sand dunes, which are almost absent in other parts of the Sundarbans) where spotted deer abundance is comparatively higher than in other areas of the Sundarbans (Dey 2004). As a result, previous studies may have failed to capture the variable spectrum of the tiger's dietary profile, particularly for spotted deer and wild pig over large spatial scales (Reza et al. 2001, Khan 2008). Because the Sundarbans contains a range of vegetation types in relation to salinity gradients (Karim 2004, Iftekhar \& Islam 2004a), these habitats are likely to influence patterns of prey distribution and their relative abundance (Dey 2004). Therefore, the results of the present study highlight the importance of representative sampling approaches for understanding the feeding patterns of tigers or other wide-ranging carnivores living over widespread geographic landscapes.

\subsection{Prey availability and preference}

The diet profile of tigers in the Sundarbans mangrove forests appears to be quite unique compared to other tiger landscapes in terms of the limited prey species consumed and the quantity of non-food items ingested. For example, $23 \%$ of the scat samples comprised more than $97 \%$ soil (except crabs and fish remains) and were devoid of any major prey items, a finding not reported before from any tiger landscapes in India (Andheria et al. 2007), Bhutan (Wang \& Macdonald 2009) and Far East Russia (Kerley et al. 2015). Whilst the actual reason for ingestion of large volume of soil remains unknown, a large number of scats with substantial amounts of soil suggests that soil ingestion is a regular phenomenon in the Sundarbans mangrove habitat. Two specific observations might explain this unusual feeding habit of tigers. Firstly, limited prey species as well as the lack of sufficient prey animals compared to other tiger landscapes (Table 4) may force tigers to feed on whatever they find on their hunting trails, including tiny crabs and fishes as supplementary food items. Secondly, because most of the soil-rich scats were found to contain remains of crabs and fishes, it is plausible that tigers might be compelled to ingest mud when they catch crabs and fishes that inhabit narrow creeks and rivers 


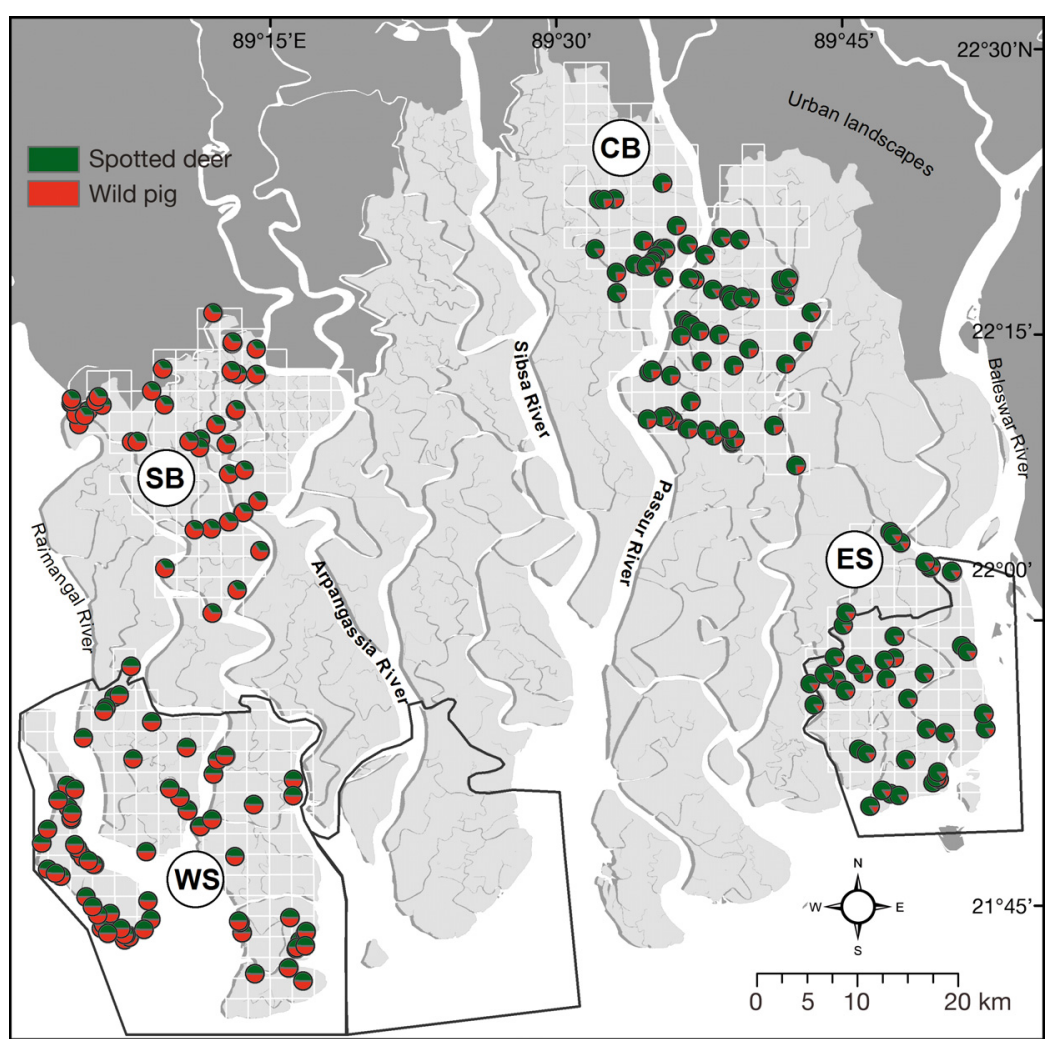

Fig. 4. Spatial distribution of relative biomass of the 2 major prey species of tigers in 4 sample blocks of the Bangladesh Sundarbans. Each pie chart shows the proportion of spotted deer and wild pig biomass as given in Table 2 . Abbreviations as in Fig. 1
Acknowledgements. We are thankful to the Chief Conservator of Forest for providing research and CITES permits for this study. Divisional Forest Officers of the East and West Divisions as well as the Wildlife and Nature Conservation Circle of the Sundarbans along with field staff extended their support during our fieldwork. This study would not have been possible without the collective effort of our survey teams comprising local fishermen and honey hunters. We are grateful to the staff of WildTeam, especially Adam Barlow, Mohammad Shamsuddoha, Iqbal Hussain, Rezvin Akter, Mahbubul Alam, Nasir Uddin, Abdullah Al Mamun, Alam Howlader, Rubyat Ahmed, Rezu Azam, Sohel Ahmed and Amit Mondol for their support during this study. M.A.A. was awarded with a Commonwealth Scholarship by the Commonwealth Scholarship Commission, UK, and the fieldwork was supported by the Panthera and WildTeam's Bagh Conservation Activity project financed by USAID Bangladesh. Thanks also to John Goodrich, Tola Smith at Panthera and Simon Tollington, Debbie Fogell and Hazel Jackson at DICE of the University of Kent. All biological samples were transported from Bangladesh to the UK under CITES permit no. BD 9118404 and authorised by the Department for Environment, Food and Rural Affairs, UK (AHVLA authorisation: TARP/2015/111). We are grateful to 2 anonymous reviewers whose comments greatly improved the quality of the manuscript.

\section{LITERATURE CITED}

with embankments formed from large layers of soft clay. The remains of grass blades and tree leaves in scats appeared to be incidentally ingested while eating prey animals, corresponding to the observations reported in previous studies (Khan 2008).

From a legal perspective, wildlife sanctuaries are more protected as managed areas of Sundarbans tiger habitat than reserve forest areas in terms of resource extraction and human access. It is therefore reasonable to expect a higher abundance of prey species in these sanctuaries than in reserve forest survey blocks. However, we found an east-west spatial pattern of tiger dietary preference for spotted deer and wild pig across the Sundarbans when in fact there is negligible variation in the distributions of these species between sampled wildlife sanctuaries and reserve forests. This finding suggests that reserve forest blocks are equally critical for tigers, and therefore, robust measures should be put in place to protect their major prey, spotted deer and wild pigs across the entire Sundarbans, irrespective of the status of sanctuary and reserve forests.
Ackerman BB, Lindzey FG, Hemker TP (1984) Cougar food habits in southern Utah. J Wildl Manag 48:147-155

Ahmad MIU, Greendwood CJ, Barlow ACD, Islam MA, Hossain ANM, Khan MMH, Smith JLD (2009) Bangladesh Tiger Action Plan 2009-2017. Ministry of Environment and Forests, Bangladesh Forest Department, Dhaka

Andheria AP, Karanth KU, Kumar NS (2007) Diet and prey profiles of three sympatric large carnivores in Bandipur Tiger Reserve, India. J Zool (Lond) 273:169-175

Aziz MA (2017) Population status, threats and evolutionary conservation genetics of Bengal tigers in the Bangladesh Sundarbans. PhD thesis, University of Kent

Aziz A, Barlow ACD, Greenwood CG, Islam A (2013) Prioritizing threats to improve conservation strategy for the tiger Panthera tigris in the Sundarbans Reserve Forest of Bangladesh. Oryx 47:510-518

Aziz MA, Tollington S, Barlow A, Goodrich J, Shamsuddoha M, Islam MA, Groombridge JJ (2017a) Investigating patterns of tiger and prey poaching in the Bangladesh Sundarbans: implications for improved management. Glob Ecol Conserv 9:70-81

Aziz MA, Tollington S, Barlow A, Greenwood C and others (2017b) Using non-invasively collected genetic data to estimate density and population size of tigers in the Bangladesh Sundarbans. Glob Ecol Conserv 12:272-282

Aziz MA, Smith O, Barlow A, Tollington S, Islam MA, Groombridge JJ (2018) Do rivers influence fine-scale population 
genetic structure of tigers in the Sundarbans? Conserv Genet 19:1137-1151

Biswas S, Sankar K (2002) Prey abundance and food habit of tigers (Panthera tigris tigris) in Pench National Park, Madhya Pradesh, India. J Zool (Lond) 256:411-420

Blower J (1985) Sundarbans Forest Inventory Project, Bangladesh: wildlife conservation in the Sundarbans. Overseas Development Administration, Surbiton

Buckland S, Anderson D, Burnham K, Laake J (2001) Distance sampling: estimating abundance of biological populations. Oxford University Press, Oxford

Canonizado JA, Hossain MA (1998) Integrated forest management plan for the Sundarbans reserved forest. Mandala Agricultural Development Corporation and Forest Department, and Ministry of Environment and Forests, Dhaka

Chaffey DR, Miller FR, Sandom JH (1985) A forestry inventory of the Sundarbans, Bangladesh. Overseas Development Administration, Surbiton

Curtis SJ (1933) Working plans for the forests of the Sundarbans Division for the period from 1931 to 1951. Bengal Government Press, Calcutta

Dey TK (2004) Deer population in the Bangladesh Sundarbans. The Ad Communication, Dhaka

Floyd TJ, Mech LD, Jordan PJ (1978) Relating wolf scat contents to prey consumed. J Wildl Manag 42:528-532

Giri C, Pengra B, Zhu Z, Singh A, Tieszen LL (2007) Monitoring mangrove forest dynamics of the Sundarbans in Bangladesh and India using multi-temporal satellite data from 1973 to 2000. Estuar Coast Shelf Sci 73:91-100

* Gopal B, Chauhan M (2006) Biodiversity and its conservation in the Sundarban Mangrove Ecosystem. Aquat Sci 68: 338-354

Hayward MW, Jedrzejewski W, Jedrzewska B (2012) Prey preferences of the tiger Panthera tigris. J Zool (Lond) 286: 221-231

Hussain Z, Acharya G (1994) Mangroves of the Sundarbans, Vol II: Bangladesh. IUCN, Bangkok

Iftekhar MS, Islam MR (2004a) Degeneration of Bangladesh's Sundarbans mangroves: a management issue. Int Rev 6: 123-135

Iftekhar MS, Islam MR (2004b) Managing mangroves in Bangladesh: a strategy analysis. J Coast Conserv 10: 139-146

Iftekhar MS, Saenger P (2008) Vegetation dynamics in the Bangladesh Sundarbans mangroves: a review of forest inventories. Wetlands Ecol Manag 16:291-312

Jacobs J (1974) Quantitative measurement of food selection. Oecologia 14:413-417

Johnsingh AJT (1983) Large mammalian prey and predators in Bandipur, India. J Bombay Nat Hist Soc 80:1-57

Kapfer PM, Streby HM, Gurung B, Simcharoen A, McDougal CC, Smith JLD (2011) Fine-scale spatio-temporal variation in tiger Panthera tigris diet: effect of study duration and extent on estimates of tiger diet in Chitwan National Park, Nepal. Wildl Biol 17:277-285

Karanth KU, Sunquist ME (2000) Behavioural correlates of predation by tiger (Panthera tigris), leopard (Panthera pardus) and dhole (Cuon alpinus) in Nagarahole, India. J Zool (Lond) 250:255-265

Karanth UK, Sunquist ME, Sunquist ME (1995) Prey selection by tiger, leopard and dhole in tropical forests. J Anim Ecol 64:439-450

Karanth KU, Nichols JD, Kumar NS, Link WA, Hines JE (2004) Tigers and their prey: predicting carnivore densities from prey abundance. Proc Natl Acad Sci USA 101:4854-4858

Karim A (2004) Implications on ecosystems in Bangladesh. In: Mirza MMQ (ed) The Ganges water dispersion: environmental effects and implications. Kluwer Academic Pub- lishers, Dordrecht, p 125-161

Kerley LL, Mukhacheva AS, Matyukhina DS, Salmanova E, Salkina GP, Miquelle DG (2015) A comparison of food habits and prey preference of Amur tiger (Panthera tigris altaica) at three sites in the Russian Far East. Integr Zool 10:354-364

Khan MMH (2008) Prey selection by tigers Panthera tigris (Linnaeus 1758) in the Sundarbans East Wildlife Sanctuary of Bangladesh. J Bombay Nat Hist Soc 105:255-263

*Mills LS, Soulé ME, Doak D (1993) The keystone-species concept in ecology and conservation. Bioscience 43:219-224

Miquelle DG, Smirnov EN, Quigley HG, Hornocker MG, Nikolaev IG, Matyushkin EN (1996) Food habits of Amur tigers in Sikhote-Alin Zapovednik and the Russian Far East, and implication for conservation. J Wildl Res 1:138-147

Miquelle D, Goodrich J, Smirnov E, Stephens PA and others (2010) Amur tiger: a case study of living on the edge. In: MacDonald D, Loveridge A (eds) The biology and conservation of wild felids. Oxford University Press, Oxford, p 325-339

* Mohsanin S, Barlow ACD, Greenwood CJ, Islam MA, Kabir MM, Rahman MM, Howlader A (2013) Assessing the threat of human consumption of tiger prey in the Bangladesh Sundarbans. Anim Conserv 16:69-76

* Power ME, Tilman D, Estes JA, Menge BA and others (1996) Challenges in the quest for keystones: Identifying keystone species is difficult - but essential to understanding how loss of species will affect ecosystems. Bioscience 46: 609-620

Reza A, Feeroz M, Islam M (2001) Food habits of the Bengal tiger (Panthera tigris tigris) in the Sundarbans. Bangladesh J Zool 29:173-179

Richardson J (2020) Selectapref: analysis of field and laboratory foraging. $\mathrm{R}$ package version 0.1.2. https://CRAN.Rproject.org/package =selectapref

Sahgal B, Grewal B, Sen S (2007) The Sundarban inheritance. Sanctuary Asia, Mumbai

Sanderson E, Forrest J, Loucks C, Ginsberg J and others (2006) Setting priorities for the conservation and recovery of wild tigers: 2005-2015. In: Tilson R, Nyhas PJ (eds) Tigers of the world - the science, politics, and conservation of Panthera tigris. Academic Press, London, p 143-161

Seidenstricker J, Hai MA (1983) The Sundarbans wildlife management plan: conservation in the Bangladesh coastal zone. International Union for Conservation of Nature and Natural Resources, Gland

Seidenstricker J, Christie S, Jackson P (1999) Overview. In: Seidenstricker J, Christie S, Jackson P (eds) Riding the tiger: tiger conservation in human-dominated landscapes. Cambridge University Press, Cambridge, p 1-4

Sunquist ME (1981) The social organization of tigers (Panthera tigris) in Royal Chitawan National Park, Nepal. Smithsonian Institution Press, Washington, DC

Sunquist M, Karanth UK, Sunquist F (1999) Ecology, behaviour and resilience of the tiger and its conservation needs. In: Seidensticker J, Christie S, Jackson P (eds) Riding the tiger: tiger conservation in human-dominated landscapes. Cambridge University Press, Cambridge, p 5-18

Wahid SM, Babel MS, Bhuiyan AR (2007) Hydrologic monitoring and analysis in the Sundarbans mangrove ecosystem, Bangladesh. J Hydrol (Amst) 332:381-395

Wang SW, Macdonald DW (2009) Feeding habits and niche partitioning in a predator guild composed of tigers, leopards and dholes in a temperate ecosystem in central Bhutan. J Zool (Lond) 277:275-283

Wikramanayake ED, Dinerstein E, Robinson JG, Karanth U and others (1998) An ecology-based method for defining priorities for large mammal conservation: the tiger as case study. Conserv Biol 12:865-878 